NBER WORKING PAPER SERIES

\title{
OPENNESS, SPECIALIZATION, AND \\ PRODUCTIVITY GROWTH IN LESS \\ DEVELOPED COUNTRIES
}

\author{
Diana Weinhold \\ James E. Rauch
}

Working Paper 6131

\author{
NATIONAL BUREAU OF ECONOMIC RESEARCH \\ 1050 Massachusetts Avenue \\ Cambridge, MA 02138 \\ August 1997
}

We would like to thank seminar participants at U.C.-San Diego, Vanderbilt University, Syracuse University, the Board of Governors, University of Kansas at Lawrence and the University of Southern Illinois at Carbondale. This paper is part of NBER's research program in International Trade and Investment. Any opinions expressed are those of the authors and not those of the National Bureau of Economic Research.

(C) 1997 by Diana Weinhold and James E. Rauch. All rights reserved. Short sections of text, not to exceed two paragraphs, may be quoted without explicit permission provided that full credit, including $(\mathcal{O}$ notice, is given to the source. 
Openness, Specialization, and Productivity Growth

in Less Developed Countries

Diana Weinhold and James E. Rauch

NBER Working Paper No. 6131

August 1997

JEL Nos. F43, O40

International Trade and Investment

\section{ABSTRACT}

Many empirical studies have found a positive relationship between openness and growth in per capita GDP in less developed countries, and economists have produced many explanations for this correlation. However, the existing studies are consistent with all of these theories and thus do not provide direct evidence in support of any one of them. Quah and Rauch [18] show how increased openness to international trade can lead to increased specialization in models of endogenous growth through learning by doing. These models imply that increased specialization accelerates productivity growth by more fully realizing dynamic economies of scale. In order to test the hypothesis that specialization increases productivity growth in LDCs we first define a Herfindahl index of production specialization for the manufacturing sector in 39 countries. We then present a series of dynamic panel regressions controlling for country fixed effects which show that, for the less developed countries, the index of specialization is positively and significantly correlated with manufacturing productivity growth. We test the robustness of this correlation by including different variables that have been associated with growth in the regressions, such as openness, inflation, government spending, and investment.

Diana Weinhold

Department of Economics and Business Administration Box 1819, Station B

Vanderbilt University

Nashville, TN 37235
James E. Rauch

Department of Economics

University of California, San Diego

La Jolla, CA 92093-0508

and NBER

jrauch@weber.ucsd.edu 


\section{Introduction}

Many empirical studies have found a positive relationship between openness to international trade and growth in per capita GDP in less developed countries (LDC's). Good surveys of this literature include Roubini and Sala-i-Martin [20] and Edwards[5]. While most of these studies have been purely cross-sectional, panel studies have begun to appear (for example, Quah and Rauch[18] and Harrison[8]). Notably, none of these studies has found a negative relationship between openness and growth.

Economists have produced many theoretical explanations for this positive relationship ${ }^{1}$. (Again, see Roubini and Sala-i-Martin [20] and Edwards [5] for a more detailed discussion.) Several of these explanations have particular relevance to the case of less developed countries ${ }^{2}$. One of these is that openness promotes more rapid absorption of technological knowledge from the developed world (see Edwards[4]). Grossman and Helpman[6] build on Krueger[10] to suggest that openness reduces rent-seeking that diverts resources from activities that generate growth. Finally, it has been suggested that openness allows economies to take full advantage of dynamic economies of scale associated with learning by doing (see, for example, Meier [15] or Quah and Rauch [18]).

The existing empirical studies are consistent with all of the explanations of how openness affects growth and thus do not provide direct evidence in support of any one of them. Most studies employ measures of openness such as trade shares of GDP, measures of price distortions, or more subjective indices of the restrictiveness of trade barriers (see Leamer [12] for a good survey of the various measures of openness). Thus, they mostly differ in their definition of what measure more accurately captures the idea of "openness", without actually testing the validity

\footnotetext{
1 The leading explanation for why openness might slow growth is that, given an unlucky set of initial conditions, openness can cause countries to specialize production in goods that experience relatively slow learning by doing (for example, see Lucas [14]).

2 Of course, by focusing on only those theories that are applicable to LDC's we must exclude from the discussion the rich literature on the effects of trade on the worldwide rate of endogenous technological progress (e.g. Grossman and Helpman [7] and Rivera-Batiz and Romer[19]).
} 
of any of the particular mechanisms hypothesized above. In this paper we attempt to obtain evidence for a mechanism linking openness and growth that is described by Quah and Rauch[18].

The structure of this paper is as follows: section two reviews the Quah and Rauch[18] model, section three describes the data, section four outlines the econometric method, section five discusses the results and section six concludes. Tables and regression results are presented in appendix A.

\section{Openness, Specialization and Growth in the Quah and Rauch Model}

In an effort to develop theory with both a microeconomic basis and some possibility of empirical testing, Quah and Rauch[18] present a model based on several common themes in the literature. They begin by borrowing a growth mechanism from Lucas[14] (section 5). In his model technical advances in production are based on learning by doing in each goods sector, and each sector varies by an individual "coefficient of learning," $\delta_{i}$, so that the accumulation of human capital follows the process

$$
\dot{h}_{i t}=\delta_{\mathrm{i}} h_{i t} u_{i t}
$$

where $u_{i t}$ is the proportion of the labor force dedicated to sector $i$ at time $t$. Therefore specialized knowledge in a given sector grows at a rate proportional to the employment in that sector.

This knowledge feeds, in turn, into Ricardian production functions. For a given aggregate employment $N$, output $x_{i}$ in sector $i$ is the product of that sector's human capital and employment level:

$$
x_{i t}=h_{i t} u_{i t} N_{t}
$$

Thus the growth rate of output per worker in sector $i$ is given by $\delta_{i} u_{i}$ and hence is increasing in specialization of resources in that sector. It is important to note that in this formulation learning by doing is not subject to diminishing returns and thus gives rise to unbounded productivity growth. Quah and Rauch interpret this feature as an indication that the model is most appropriate for less devel- 
oped countries, which face a continually and exogenously expanding technological frontier as determined by ongoing R\&D activity in developed economies. Because the LDC's never quite catch up in their own technological development, they can continue to ride on others' research and thereby escape diminishing returns.

It is this link between specialization and productivity growth that we shall test below. The contribution of Quah and Rauch is to show how openness can determine the level of specialization in the Lucas model when it is combined with certain features suggested by LDC experience. In particular, the literature that examines LDCs following relatively self-sufficient (inward-oriented) economic policies finds problems caused by insufficient growth of intermediate good sectors. For instance, Kreuger[11] states that, following attempts at import-substitution development,

"Dependence" upon imports for final consumption goods was replaced by "dependence" upon imports for growth not only via the availability of capital goods but also for employment and output, because the newly established factories could not produce without imported intermediate goods and raw materials.

The growth consequences of these input bottlenecks motivated development of the two-gap model of economic growth during the 1960s (see, e.g., Chenery and Strout[3]). The LDC experience therefore suggests low production elasticities of substitution: the economy cannot specialize around intermediate good sectors that are growing only slowly.

Let us therefore interpret the sectors above as intermediate goods, and consider what happens to relative employment and thus relative productivity growth when human capital in sector $n$ exceeds that in sector $j$. Directly, there is a one-for-one negative effect: it takes fewer labor units to produce the same quantity of sector $n$ output. Indirectly, there is a positive effect on relative employment in sector $n$ because higher productivity there leads to a lower relative price. With a less-thanunitary elasticity of substitution in production, the negative effect dominates and lower employment results in sectors that have higher human capital. Thus more rapid productivity growth in any intermediate goods sector undoes itself, and in 
autarky the economy is unable to specialize around slowly-growing intermediate goods, instead producing the full range. Aggregate growth in the steady state is therefore limited to the growth rate of the slowest growing intermediate goods sector.

How does openness affect growth in this story? The slowest-learning (lowest $\delta)$ intermediate goods have the highest autarky prices in order to attract enough labor resources to allow their output (productivity) to grow at the same rate as all other goods. Opening to international trade then naturally eliminates these bottlenecks through imports, allowing greater specialization in production of the remaining goods. This greater specialization in turn generates higher productivity growth as in the Lucas model. Note that rising imports imply a greater trade share, which is therefore an appropriate measure of openness in the Quah and Rauch model.

In their paper Quah and Rauch test for a positive relationship between openness as measured by the trade share and per capita GDP growth. In this paper we address the question of the underlying mechanisms by examining the relationship between specialization and manufacturing productivity growth. We also check that the trade share is indeed positively correlated with specialization within the manufacturing sector. Our focus on the manufacturing sector seems appropriate as most of the examples of 'learning by doing' in the empirical literature refer to the manufacturing sector.

\section{Data Sources and Variable Definitions}

\subsection{Data sources}

We now turn our attention to our data sources and the specific definitions of the variables. For convenience, an abbreviated list of the regression variables with brief definitions is provided in appendix D. The data compiled for this study come from three sources: the UNIDO tables at the World Bank, the World Tables available from the World Bank and the Summers and Heston Penn Mark V tables. 
Data was collected from 1960 to 1990 for 39 countries $^{3}$. Appendix C contains a detailed accounting of which countries were used in each regression.

\subsection{Herfindahl Specialization Variables}

Three measures of specialization within the manufacturing sector were constructed for the empirical analysis. Data was collected from the UNIDO database at the World Bank. For each country yearly data was collected on gross output and value-added for each of 28 different manufacturing industries, which are listed in appendix B. All of the measures of specialization are adaptations of the Herfindahl index ${ }^{4}$.

The first Herfindahl index is based on gross-output in manufacturing and is defined as:

$$
\text { GOHERF }_{i t}=\sum_{i=1}^{I}\left[y_{i t} / Y_{t}\right]^{2}
$$

where $i=1 \ldots I$ refer to different industries within the manufacturing sector, $y_{i t}$ refers to gross output of a particular industry $i$ in time $t$ and $Y_{t}$ refers to the total gross output of the manufacturing sector in time $t$.

$V A H E R F$ is similarly defined but is based on value-added in each sector so that:

$$
V A H E R F_{i t}=\sum_{i=1}^{I}\left[v_{i t} / V_{t}\right]^{2}
$$

where $v_{i t}$ is value-added in industry $i$ at time $t$ and $V_{t}$ is total value-added at time $t$.

A weighted Herfindahl indicex was constructed to test whether specialization in more value-added intensive industries affected growth of productivity more

\footnotetext{
${ }^{3}$ Some countries did not have data for the full sample period and not all countries were used in each regression (see appendix $\mathrm{C}$ ).

4 This index was also used as a measure of export concentration in Backus, Kehoe and Kehoe[2]. They note that for some assumed production functions, "in general. . the appropriate specialization index is based on other powers of the output shares $y_{i t} / Y_{t}$, but we think that this simple measure captures the dispersion of production across industries." p.389.
} 
than the basic specialization indices. This weighting scheme constitutes a crude attempt to capture the idea that specialization in "high learning" (high $\delta$ ) industries may be associated with more "learning by doing", and hence with higher productivity growth, than an equal amount of specialization in lower $\delta$ industries. WTHERF is an index of specialization in gross-output weighted by each industry's value-added per employee, so that industries with a higher proportion of value added per employee receive a greater weight. More formally:

$$
W T H E R F_{i t}=\sum_{i=1}^{I}\left[\left[\left(v_{i t} / l_{i t}\right) / \sum_{i=1}^{I} v_{i t} / l_{i t}\right] *\left[y_{i t} / Y_{t}\right]\right]^{2}
$$

where $l_{i t}$ is employment in industry $i$ at time $t$.

All of these indices of specialization can take values between 0 and 1 , with higher values corresponding to increased specialization. In table 1 we present some basic summary statistics for all three measures. As should be expected, specialization is higher among the less developed countries, who also have greater variability in the degree of specialization than do the industrialized countries in the data set.

Finally, although the ultimate purpose of this paper is to examine the relationship between productivity growth and specialization, the link from increased trade to higher growth posited by the Quah and Rauch model also implies that there should be a correlation between openness to trade as measured by the trade share of GDP (denoted as $T V A L$ ) and specialization. In table 2 we analyze the correlation between $T V A L$ and all three of our specialization variables using annual data, differentiating between less developed and industrialized countries. We observe that all of the specialization indices for less developed countries are significantly and positively correlated with trade share. The weighted Herfindahl index for industrialized countries is not significantly correlated with our measure of openness, however. 


\subsection{Productivity growth: the dependent variables}

The productivity growth variables that we use for this analysis are measures of labor productivity rather than the preferred concept of total factor productivity. This is due to a lack of data on cross-country manu facturing capital stocks (as opposed to overall capital stock). Thus without additional data it is empirically impossible to control for level of manufacturing capital stock when measuring labor productivity. However, despite the difficulties with data availability, we feel that by linking measures of manufacturing specialization to some measures of productivity growth in manufacturing, our method improves on the standard practice of using GDP growth as the dependent variable even when the underlying theory may have been developed with the manufacturing sector in mind.

Throughout most of the empirical analysis we consider two different measures of labor productivity as our dependent variable. A measure of growth in manufacturing labor productivity (GPROD) was used from the World Bank's World Tables ${ }^{5}$ using data on gross output per employee. For comparison, a second measure was constructed from the UNIDO data set of growth of manufacturing value-added per employee ( $G V A P R O D)$. The means and standard deviations of both of these measures of productivity growth are provided in table 3 .

\subsection{Additional control variables}

In addition to the specialization indices which are the variables of immediate interest, additional control variables were included in the regressions. The "fixed effects" or time-invariant component of each country are controlled for either directly through the use of country-specific dummy variables in the first set of regressions, or their effects are eliminated via first differencing in the second set of regressions.

Certainly an important component of economic growth is the rate of investment, and it is thus important to control for its effect when examining the role of other variables on growth. However the feedback between these two variables

\footnotetext{
${ }^{5}$ The source variable for GPROD in the World Tables is MAN.ROUT.EMPL.
} 
may cause serious simultaneity bias in such a regression. It should be pointed out that the investment we are controlling for in our models is a measure of aggregate fixed investment in the economy, rather than manufacturing investment. Nevertheless there might still be a problem with simultaneity between the growth of manufacturing labor productivity and the growth of aggregate investment. Thus in all the models we instrument for the growth of fixed investment, using lags of this variable and lags of other control variables of the model as instruments ${ }^{6}$.

We have chosen to use the growth of fixed investment rather than the level share of investment in GDP due to the debate as to whether investment share of GDP is nonstationary ${ }^{7}$. Certainly investment share as a variable displays much more time persistence than, for example, GDP growth. Weinhold[21] uses a panel data method developed by Levin and Lin[13] to test for stationarity of investment share in the dataset and fails to reject the null hypothesis of a unit root in both the less developed and developed country series. The use of growth of fixed investment rather than investment share did not change the basic results ${ }^{8}$ but led to much more stable coefficient estimation on both the growth of investment and openness variables and increased the general fit of the models. (This could be due to reduced simultaneity between the investment and growth variables.) This variable is denoted $I N V I V$.

Our reduced form model includes several additional control variables commonly used in growth regressions. These include the inflation rate $(I N F)$, the share of government spending in GDP (GOVSHARE), and the level of openness as measured by the share of trade in GDP $(T V A L)$. It is especially important to include this measure of openness as it was shown in section three that the specialization indices and this variable are positively correlated. Thus, if trade share of GDP is positively correlated with productivity growth and we omit it from

\footnotetext{
${ }^{6}$ Instrumenting for the growth of fixed investment did not change the basic results but minimizes the chance of simultaneity bias in the results.

${ }^{7}$ see Weinhold[21] pp. 23-24 for a discussion of this issue.

${ }^{8}$ In other words, the signs and levels of significance on the coefficients of interest were not changed significantly by using level of investment share rather than growth of investment as a control variable.
} 
the regression a serious omitted variable bias could easily lead us to conclude that the specialization variables were significant even if they were not. Annual data on human capital were not available for an ample enough set of countries.

We also wish to allow for the possibility of a structural change in the process governing growth rates during the time period encompassed by the data. There is a considerable body of literature that notes a marked decrease in productivity growth starting in the mid seventies (see, for example, Quah[17]). In order to accomplish this in our models we include a dummy (PRE1973) for the first half of the sample (before 1973) that allows a "generic" (overall) intercept shift ${ }^{9} 10$.

\section{Econometric Method}

This paper utilizes an estimation method that exploits the full time dimension of the data by using all the information from a full panel rather than just the time-averaged information from a cross-section. We are thus able to control for unobserved but time-invariant individual heterogeneity (such as "work ethic" or country size) by introducing country- specific intercepts, or "fixed effects." For the full panel models we allow for a dynamic structure in the form of lagged independent and dependent variables. This approach has the advantage that the lagged dependent variable may capture some of the influence of unobserved variables and therefore decreases the possibility of omitted variable bias. In addition, the inclusion of an adequate lag length insures asymptotically uncorrelated errors. Following the discussion in section 2 , we expect that specialization within manufacturing industry could have a much greater impact on productivity growth in

\footnotetext{
${ }^{9}$ In addition, the country-group slope coefficients on the variables of interest were also allowed to shift from the first to the second half of the sample in earlier versions of this paper. This did not add anything interesting to the interpretation, nor did it change the basic results. Thus for this version only the intercept shift term remains, although the omission of this variable does not affect the results either.

10 A full set of yearly dummies was introduced into the estimations to test whether or not the results could be explained by individual year, time-specific effects. As this addition only marginally improved fit and did not affect the significance of the results on the specialization indices (but used up quite a few degrees of freedom), the yearly dummies were not included in the final models.
} 
less developed countries than in countries with mature economies, in which longrun technological change rather than learning by doing is likely to be the primary source of productivity growth.

The basic model in its simplest form thus becomes:

$$
\begin{aligned}
Y_{i t}= & \alpha_{i}+\delta_{j} Y_{i, t-j}+\sum_{j=0} \beta_{1 j} D_{l d c} * H E R F_{i t-j} \\
& +\sum_{j=0} \beta_{2 j} D_{d e v} * H E R F_{i t-j}+\gamma_{k j} \sum_{k=1, j=0} X_{k i t-j}+u_{i t}
\end{aligned}
$$

where $Y_{i t}$ is a measure of productivity growth, $H E R F_{i t}$ denotes a measure of specialization and $D_{l d c}$ and $D_{d e v}$ are dummies for less developed and developed countries, respectively. Finally, $X_{i t}$ is a matrix of exogenous control variables.

Several econometric issues are raised by the inclusion of lagged dependent variables in panel models with fixed effects. We adopt an estimation method that addresses these concerns.

As formally illustrated in Nickell [16], dynamic panel data models with fixed effects are subject to Hurwitz biases of order $(1 / T)$. Although the time series dimension in our panels averages 20 years per country, this problem could lead to biased estimates and distort the results.

Following Anderson and Hsiao[1], Holtz-Eakin, Newey and Rosen[9] outline a method (henceforth HNR estimation) for consistently estimating dynamic models with panel data while controlling for fixed effects. For example, consider the general model:

$$
y_{i t}=\alpha_{0}+\sum_{j=1}^{m} \alpha_{j} y_{i t-1}+\sum_{j=1}^{m} \delta_{j} x_{i t-1}+f_{i}+u_{i t}
$$

where $i=1 \ldots N$. In order to eliminate the fixed effects, $f_{i}$, the authors difference the data leading to the model:

$$
y_{i t}-y_{t-1}=\sum_{j=1}^{m} \alpha_{j}\left(y_{i t-j}-y_{t-j-1}\right)+\sum_{j=1}^{m} \delta_{j}\left(x_{i t-j}-x_{i t-j-1}\right)+\left(u_{i t}-u_{i t-1}\right)
$$


This specification introduces a problem of simultaneity because the error term is correlated with the regressor $\left(y_{i t-j}-y_{i t-j-1}\right)$. Therefore a 2SLS instrumental variables procedure with a time-varying set of instruments is used to estimate the model. As the purpose of our paper is to explore the particular relationship between specialization and productivity growth rather than to estimate a panel VAR system, we adapt this methodology slightly to allow for contemporaneous exogenous variables. Thus our final model becomes:

$$
y_{i t}-y_{t-1}=\sum_{j=1}^{m} \alpha_{j}\left(y_{i t-j}-y_{t-j-1}\right)+\sum_{j=0}^{m} \delta_{j}\left(x_{i t-j}-x_{i t-j-1}\right)+\left(u_{i t}-u_{i t-1}\right)
$$

where the $x$ variables include our specialization index as well as the set of additional control variables.

The advantage of the HNR estimation method is that it produces consistent estimates while allowing for both a dynamic structure and for the fixed effects of the countries in the panel. However, there are too few degrees of freedom to estimate country specific dynamics and still retain much power of the tests of hypotheses ${ }^{11}$. The lagged dependent variable is instrumented using a time-varying set of instruments along the lines suggested in Holtz-Eakin et. al.. Originally five lags were included in the model and the longest lags systematically eliminated if they were not statistically significant. Thus the final model has three lags of the endogenous variable to ensure asymptotically consistent estimation. Both contemporaneous and lagged exogenous variables were also included in the model and FGLS was employed to insure heteroskedasticity-consistent standard errors and $t$-tests.

11 The authors did estimate the models allowing the first lag only of the endogenous variable to vary from country to country. The signficance of the coefficients of the exogenous specialization variables was quite robust to these changes in model specification. Nevertheless only those models more closely adhering to the HNR technique are presented in this paper. 


\section{Empirical Results}

The results presented are from dynamic panel regressions using the estimation method described in section 4 . Each regression is numbered, with the identifying number and the LHS dependent variable listed along the top horizontal axis. The independent variables are listed down the vertical axis, with the statistical significance (as determined by two-tailed heteroskedasticity-consistent $t$-tests of the coefficients) indicated in the usual way by asterisks: one * signifies significance at the $10 \%$ level, two at the $5 \%$ level, and three at the $1 \%$ level. In addition, since the variables in these models are first-differenced their name changes accordingly, acquiring the prefix " $\mathrm{D}$ ".

We first check for robustness by varying the set of control variables in the regression. In table 4 we present the results of three regressions of the growth of manufacturing labor productivity on a set of control variables and the gross-output Herfindahl index (GOHERF) interacted with dummies for developed (DEV) and less developed $(L D C)$ countries. The regression specification is fully dynamic in that the lags of both endogenous and exogenous variables are included. In regression \#1 output specialization is included as the only exogenous variable other than the time and country dummies. Regression \# 2 adds the (instrumented) investment variable to this specification, and regression \# 3 further adds the openness variable TVAL. The subsequent regressions presented in the rest of the paper include the full set of control variables that add GOVSHARE and INF to the model ${ }^{12}$. In all of these models the specialization variables are significant and positive for less developed countries, but not significant for the developed countries. These regressions illustrate that the significance and general magnitude of the coefficients of the specialization variables are robust to different model specifications.

We now turn to analyzing the coefficients on the three different specialization

${ }^{12}$ Other model specifications varying the set of control variables yielded similar results in terms of the significance of the specialization variables, but due to space considerations only these representative regressions are presented. 
variables when accompanied in a regression by the full set of control variables. The primary results are presented in tables 5 and 6 where the coefficient estimates and their associated (heteroskedasticity consistent) t-statistics are presented side-byside to save space.

In table 5 our dependent variable, $D G P R O D$, is defined using gross output per employee. As this variable originates from a completely different data as our specialization variables, there is less chance that some general data error could lead to a correlation between them. Regressions \# 4 and 5 show that both the gross-output based and the value-added based specialization variables for less developed countries are positive and significant. The lagged values fluctuate between positive and negative, as is common for this type of analysis, but are not statistically significant. As with regressions \#'s 1,2, and 3 the specialization variables for industrialized countries are not statistically significantly different from zero. The weighted Herfindahl variable is not significant for either less developed or industrialized countries.

The Herfindahl indices' coefficient estimates are themselves not easily comparable, so in order to get some idea of the economic magnitude of the coefficients we calculate the change in growth of productivity precipitated from a one standard deviation change in each specialization variable (for less developed countries), holding all other control variables constant. Due to strong correlation with $T V A L$ (and perhaps other control variables) it is perhaps unrealistic to expect that the values of the other control variables would ever remain constant if specialization were increased, so these estimates should be interpreted with caution and are meant to be used for comparison purposes only. The estimated contemporaneous change in the growth of productivity associated with a one standard deviation increase in the specialization variables for the less developed country from regressions \# 4 and 5 are 0.094 and 0.045 for GOHERF and $V A H E R F$, respectively (the coefficient for WTHERF is not statistically significant), quite substantial effects relative to the mean of 0.033 reported in table 3 . We also see from table 3 that these effects translate into respective changes of 1.05 and 0.51 standard deviations of the dependent variable. Thus it seems that the gross-output based 
index has the biggest effect on the gross-output based productivity measure.

It could be argued, however, that increased value-added per worker is more important for the long run growth of an economy in that gross-output per employee may be inflated by the presence of "maquiladora" type assembly plants that lead to relatively less knowledge and technical externalities. To test whether the specialization indices are significantly correlated with a productivity growth measure based on manufacturing value-added per employee, we construct a second dependent variable, $D G V A P R O D$. In table 6 we present a second set of panel data estimations using $D G V A P R O D$ as the dependent variable. In this case we see that the gross-output specialization variable for less developed countries does not provide significant explanatory power for the growth of manufacturing valueadded per employee. However, both the value-added and the weighted specialization indices for less developed countries are statistically significant and positively correlated with the dependent variable, with a one standard deviation change in specialization precipitating contemporaneous changes in the dependent variable of 0.608 and 0.957 standard deviations, respectively ${ }^{13}$. As with all the previous analysis, the specialization indices are not significant for the industrialized countries $^{14}$.

This empirical analysis shows strong evidence that specialization in less developed countries is significantly and positively correlated with productivity growth, even when controlling for other variables commonly found in growth regressions. This is in direct contrast to the relationship in industrialized countries where

13 From table 3 the mean and standard deviation of GVAPROD are 0.027 and 0.1044 , respectively.

${ }^{14}$ In earlier versions of this paper we analyzed the relationship between specialization and productivity growth using six-year averaged data. Estimation with this lower frequency data precluded the use of dynamics and substantially reduced the degrees of freedom in the estimation. Nevertheless we find that both GOHERF and $V A H E R F$ are significantly and positively related to the GVAPROD productivity measure. The specialization variables were not significantly correlated with the GPROD variable, however. This result could be due either to the lack of long run relationships between specialization and gross-output productivity growth, or it could be due to the various modeling problems including the low power of the estimation relative to the full panel or the lack of dynamic structure. 
specialization seems to have no direct impact on productivity growth. The evidence for specialization in more value-added intensive industries leading to greater growth effects than overall specialization is less strong. While the value-added specialization variable did have the largest influence on the growth of value-added productivity, it did not have as large an impact on the growth of gross-output productivity as did the gross-output specialization variable.

\section{Conclusion}

While several theoretical models of development have predicted a positive correlation between openness and growth, the empirical literature has focused on the correlation itself while remaining rather silent on the issue of the mechanism through which this relationship might occur. In this paper we have attempted to utilize appropriate econometric techniques to focus on a particular channel hypothesized in Quah and Rauch[18] through which increased openness could lead to greater growth rates in less developed countries. Quah and Rauch show how increased openness to international trade can lead to increased specialization in models of endogenous growth through learning by doing. These models imply that increased specialization accelerates productivity growth by more fully realizing dynamic economies of scale.

While we could not test the Quah and Rauch model completely, we found substantial evidence to support the hypothesis that specialization in the manufacturing sector increases the rate of growth of manufacturing productivity in less developed countries. Thus we may have captured one possible mechanism through which increased trade may lead to growth. Certainly there may be other channels still unaccounted for, and additional research is necessary to explain the openness-growth relationship. 


\section{A. Tables}

Table 1: Summary Statistics for Herfindahl Specialization Indices

\begin{tabular}{|c|c|c|c|}
\hline Variable & $\mathrm{N}$ & Mean & Std Dev \\
\hline GOHERF-LDC & 411 & 0.11450 & 0.04380 \\
\hline GOHERF-DEV & 143 & 0.07296 & 0.00948 \\
\hline VAHERF-LDC & 390 & 0.10105 & 0.03715 \\
\hline VAHERF-DEV & 142 & 0.06490 & 0.00498 \\
\hline WTHERF-LDC & 363 & 0.00378 & 0.00283 \\
\hline WTHERF-DEV & 142 & 0.00211 & 0.00020 \\
\hline
\end{tabular}

Table 2: Annual-Data Correlation Between TVAL and Specialization Variables

\begin{tabular}{|c|c|c|}
\hline Variable 1 & $\begin{array}{c}\text { Pearson Correlation } \\
\text { Coefficient }\end{array}$ & $\begin{array}{c}p-\text { value } \\
\text { under } \text { Ho: } \rho=0\end{array}$ \\
\hline GOHERF-LDC & 0.33238 & 0.0001 \\
\hline GOHERF-DEV & 0.48049 & 0.0001 \\
\hline VAHERF-LDC & 0.30012 & 0.0001 \\
\hline VAHERF-DEV & 0.28023 & 0.0001 \\
\hline WTHERF-LDC & 0.32403 & 0.0001 \\
\hline WTHERF-DEV & 0.04912 & 0.4624 \\
\hline
\end{tabular}

Table 3: Summary Statistics for Productivity Growth

\begin{tabular}{|ccc|}
\hline Variable & Mean & Std Dev \\
\hline GPROD & 0.0330 & 0.0892 \\
GVAPROD & 0.0272 & 0.1044 \\
\hline
\end{tabular}


Table 4: HNR Panel Estimation of DGPROD

\begin{tabular}{|c|c|c|c|c|c|c|}
\hline \multirow[t]{2}{*}{ regression: $H E R F=$} & \multicolumn{2}{|c|}{ (1) $G O H E R F$} & \multicolumn{2}{|c|}{ (2) GOHERF } & \multicolumn{2}{|c|}{ (3) GOHERF } \\
\hline & coeff. & t-stat & coeff. & t-stat & coeff. & t-stat \\
\hline PRE1973 & -.0087 & -.692 & 0.004 & 0.276 & 0.005 & 0.358 \\
\hline DHERF-Ldc & $1.549^{* *}$ & 2.97 & $2.229 * *$ & 5.625 & $2.302^{* * *}$ & 4.397 \\
\hline DHERF-Dev & -5.04 & -1.01 & -3.14 & -.775 & -4.25 & -.894 \\
\hline DHERF-Ldc_1 & -1.094 & -.232 & -.091 & -.022 & -1.88 & -.423 \\
\hline DHERF-Ldc_2 & -1.875 & -.394 & -3.017 & -.732 & -1.85 & -.417 \\
\hline DHERF-Ldc_3 & -2.194 & -.446 & -3.792 & -.882 & -2.97 & -.646 \\
\hline DHERF_1 & 0.062 & 0.013 & -1.050 & -.257 & 0.736 & 0.166 \\
\hline DHERF 2 & 1.497 & 0.315 & 1.952 & 0.475 & 0.563 & 0.127 \\
\hline DHERF_3 & 2.510 & 0.512 & 3.574 & 0.837 & 2.819 & 0.616 \\
\hline DINVIV & & & 0.087 & 0.802 & 0.060 & 0.531 \\
\hline DINVIV_1 & & & $0.292^{* *}$ & 2.338 & $0.323^{* *}$ & 2.447 \\
\hline DINVIV_2 & & & 0.077 & 0.607 & 0.130 & 0.993 \\
\hline DINVIV_3 & & & 0.136 & 1.323 & 0.165 & 1.553 \\
\hline DTVAL & & & & & 0.000 & 0.087 \\
\hline DTVAL_1 & & & & & -.008 & -.200 \\
\hline DTVAL_2 & & & & & -.073 & -1.611 \\
\hline DTVAL 3 & & & & & -.059 & -1.383 \\
\hline DGPRODIV_1 & $-.776^{* * *}$ & -9.309 & $-.724^{* * *}$ & -8.045 & $-.671^{* * *}$ & -7.19 \\
\hline DGPRODIV_2 & $-.361^{* * *}$ & -3.653 & $-.286^{* *}$ & -2.674 & $-.256^{* *}$ & -2.317 \\
\hline DGPRODIV_3 & $-.235^{* *}$ & -2.358 & -.159 & -1.47 & -.126 & -1.181 \\
\hline
\end{tabular}


Table 5: Estimation of DGPROD (HNR method)

\begin{tabular}{|c|c|c|c|c|c|c|}
\hline \multirow[t]{2}{*}{ regression: $H E R F=$} & \multicolumn{2}{|c|}{ (4) GOHERF } & \multicolumn{2}{|c|}{ (5) VAHERF } & \multicolumn{2}{|c|}{ (6) WTHERF } \\
\hline & coeff. & t-stat & coeff. & t-stat & coeff. & t-stat \\
\hline PRE1973 & 0.0117 & 0.77 & 0.0125 & 0.80 & 0.0009 & 0.014 \\
\hline DHERE-Ldc & 2.1457 & $3.81 * * *$ & 1.2144 & $2.11^{* *}$ & 14.49 & 1.01 \\
\hline DHERF-Dev & -5.0702 & -0.91 & -0.4395 & -0.06 & -29.01 & -0.23 \\
\hline DINF & -0.0545 & $-2.06^{* *}$ & -0.0537 & $-1.95^{*}$ & -0.064 & $-2.52^{* * *}$ \\
\hline DGOVSHARE & 1.1460 & $2.72^{* * *}$ & 1.1858 & $2.72^{* * *}$ & 0.6418 & 1.33 \\
\hline DINVIV & 0.0277 & 0.26 & 0.0223 & 0.20 & -0.0031 & 0.03 \\
\hline DTVAL & 0.0000 & 0.08 & -0.0001 & -0.27 & -0.0001 & -0.16 \\
\hline DHERF-Ldc_1 & -1.6333 & -0.29 & 5.8779 & 0.82 & 12.3687 & 0.10 \\
\hline DHERF-Ldc_2 & -3.3385 & -0.60 & -2.2928 & -0.32 & 55.1826 & 0.45 \\
\hline DHERF-Ldc_3 & -2.6447 & -0.46 & -3.4444 & -0.48 & -79.8452 & -0.66 \\
\hline DHERF_l & 0.6714 & 0.12 & -5.4653 & -0.77 & 4.1251 & 0.034 \\
\hline DHERF_2 & 2.5814 & 0.46 & 1.3262 & 0.19 & -79.845 & -0.69 \\
\hline DHERF_3 & 2.9315 & 0.51 & 3.3356 & 0.46 & 86.857 & 0.71 \\
\hline DINF_1 & 0.0753 & $2.74^{* * *}$ & 0.0600 & $2.12^{* *}$ & 0.0789 & $3.27^{* * *}$ \\
\hline $\mathrm{DINF}_{2} 2$ & 0.0102 & 0.36 & 0.0160 & 0.56 & -0.0052 & 0.21 \\
\hline DINF_3 & 0.0004 & 0.01 & -0.0039 & -0.10 & 0.0014 & 0.04 \\
\hline DGOVSHARE_1 & -0.6847 & -1.26 & -0.5711 & -1.03 & -0.7243 & -1.37 \\
\hline DGOVSHARE_2 & 0.0124 & 0.02 & 0.3265 & 0.57 & -0.4218 & -0.71 \\
\hline DGOVSHARE_3 & -0.0630 & -0.11 & -0.0352 & -0.06 & -0.263 & 0.485 \\
\hline DTVAL.1 & -0.0732 & -1.57 & -0.0927 & $-1.96^{*}$ & -0.1277 & $-2.85^{* * *}$ \\
\hline DTVAL_2 & -0.0885 & $-1.68^{*}$ & -0.0860 & -1.56 & -0.1422 & $-2.75^{* * *}$ \\
\hline DTVAL_3 & -0.0353 & -0.71 & -0.0284 & -0.56 & -0.0495 & -1.05 \\
\hline DINVIV.1 & 0.2441 & $1.75^{*}$ & 0.2195 & 1.52 & 0.3808 & $2.72^{* * *}$ \\
\hline DINVIV_2 & 0.2036 & 1.45 & 0.1806 & 1.24 & 0.1383 & 1.00 \\
\hline DINVIV_3 & 0.0693 & 0.59 & 0.0518 & 0.42 & 0.0107 & 0.091 \\
\hline DGPRODIV_1 & -0.5708 & $-5.51^{* * *}$ & -0.6454 & $-5.92^{* * *}$ & -0.5505 & $-5.99^{* * *}$ \\
\hline DGPRODIV_2 & -0.2420 & $-2.02^{* *}$ & -0.2728 & $-2.17^{* *}$ & -0.2962 & $-2.55^{* * *}$ \\
\hline DGPRODIV_3 & -0.1751 & -1.53 & -0.2434 & $-2.05^{* *}$ & -0.2836 & $-2.47^{* *}$ \\
\hline No. Obs. & \multicolumn{2}{|c|}{408} & \multicolumn{2}{|c|}{398} & \multicolumn{2}{|c|}{377} \\
\hline$R$-squared & \multicolumn{2}{|c|}{.2626} & \multicolumn{2}{|c|}{.2309} & \multicolumn{2}{|c|}{.2518} \\
\hline \multicolumn{7}{|c|}{$t$-statistics reported are heteroskedasticity-consistent } \\
\hline
\end{tabular}


Table 6: Estimation of DGV APROD (HNR method)

\begin{tabular}{|c|c|c|c|c|c|c|}
\hline \multirow[t]{2}{*}{ regression: $H E R F=$} & \multicolumn{2}{|c|}{ (7) GOHERF } & \multicolumn{2}{|c|}{ (8) VAHERF } & \multicolumn{2}{|c|}{ (9) WTHERF } \\
\hline & coeff. & t-stat & coeff. & t-stat & coeff. & t-stat \\
\hline PRE1973 & -0.0046 & -0.23 & -0.0052 & -0.26 & -0.0067 & -0.38 \\
\hline DHERF-Ldc & 0.8641 & 1.28 & 1.7081 & $2.44^{* *}$ & 35.675 & $2.47^{* *}$ \\
\hline DHERF-Dev & -2.0034 & -0.26 & 1.3460 & 0.14 & 215.930 & 1.35 \\
\hline DINF & -0.1066 & $-3.03^{* * *}$ & -0.1213 & $-3.48^{* * *}$ & -0.1204 & $-3.36^{* * *}$ \\
\hline DGOVSHARE & 0.2533 & 0.46 & 0.3185 & 0.58 & -0.1630 & 0.26 \\
\hline DINVIV & 0.0225 & 0.16 & 0.0687 & 0.48 & 0.1223 & 0.76 \\
\hline DTVAL & -0.0002 & -0.44 & -0.0002 & -0.57 & -0.0001 & -0.17 \\
\hline DHERF-Ldc_1 & -2.8995 & -0.37 & 7.1014 & 0.77 & -35.6150 & -0.23 \\
\hline DHERF-Ldc_2 & 1.8421 & 0.23 & -6.8825 & -0.74 & 98.6356 & 0.60 \\
\hline DHERF-Ldc_3 & -2.5941 & -0.32 & 2.6293 & 0.28 & 67.4234 & 0.41 \\
\hline DHERF _ 1 & 2.5165 & 0.32 & -8.3032 & -0.90 & -7.6134 & 0.05 \\
\hline DHERF_2 & -1.5941 & -0.20 & 6.4673 & 0.70 & -116.069 & -0.72 \\
\hline DHERF_3 & 2.3914 & 0.30 & -2.1553 & -0.23 & -65.4726 & -0.40 \\
\hline DINF_1 & 0.1158 & $3.20^{* * *}$ & 0.1100 & $3.10^{* * *}$ & 0.1228 & $3.19^{* * *}$ \\
\hline DINF_2 & -0.0688 & $-1.91^{*}$ & -0.0684 & $-1.95^{*}$ & -0.0814 & $-2.20^{* *}$ \\
\hline DINF_3 & -0.0370 & -0.72 & -0.0424 & -0.84 & -0.0257 & -0.49 \\
\hline DGOVSHARE_1 & 0.6953 & 0.95 & 0.7391 & 1.04 & 0.4660 & 0.67 \\
\hline DGOVSHARE 2 & -1.3107 & $-1.73^{*}$ & -1.2004 & -1.63 & -2.2622 & $-2.84^{* * *}$ \\
\hline DGOVSHARE_3 & 0.4683 & 0.62 & 0.6531 & 0.90 & 0.2949 & 0.39 \\
\hline DTVAL_1 & -0.0595 & -0.95 & -0.0516 & -0.84 & -0.0833 & -1.40 \\
\hline DTVAL_2 & -0.1039 & -1.51 & -0.0989 & -1.44 & -0.1566 & $-2.03^{* *}$ \\
\hline DTVAL_3 & -0.0496 & -0.76 & -0.0463 & -0.73 & -0.0611 & -0.99 \\
\hline DINVIV_1 & 0.3826 & $2.07^{* *}$ & 0.3737 & $2.05^{* *}$ & 0.4674 & $2.54^{* *}$ \\
\hline DINVIV_2 & 0.0232 & 0.12 & 0.1031 & 0.56 & 0.0222 & 0.13 \\
\hline DINVIV_3 & 0.0325 & 0.20 & 0.0387 & 0.25 & -0.0285 & -0.187 \\
\hline DGVAPRODIV_1 & -0.5042 & $-4.31^{* * *}$ & -0.4806 & $-4.20^{* * *}$ & -0.4559 & $-4.08^{* * *}$ \\
\hline DGVAPRODIV_2 & -0.1756 & -1.27 & -0.1329 & -0.96 & -0.2028 & -1.47 \\
\hline DGVAPRODIV_3 & -0.1726 & -1.21 & -0.1933 & -1.39 & -0.2236 & -1.59 \\
\hline No. Obs. & \multicolumn{2}{|c|}{386} & \multicolumn{2}{|c|}{388} & \multicolumn{2}{|c|}{367} \\
\hline$R$-squared & \multicolumn{2}{|c|}{.1565} & \multicolumn{2}{|c|}{.1817} & \multicolumn{2}{|c|}{.1910} \\
\hline * indicates s & \multicolumn{6}{|c|}{$t$-statistics reported are heteroskedasticity-consistent } \\
\hline
\end{tabular}


B. Manufacturing Sectors by ISIC Code

\begin{tabular}{|c|c|}
\hline ISIC Code & Description \\
\hline 311 & Food Products \\
\hline 313 & Beverages \\
\hline 314 & Tobacco \\
\hline 321 & Textiles \\
\hline 322 & Wearing Apparel, exc. Footwear \\
\hline 323 & Leather products \\
\hline 324 & Footwear, exc. Leather or Plastic \\
\hline 331 & Wood Products, exc. Furniture \\
\hline 332 & Furniture, exc. Metal \\
\hline 341 & Paper \& Products \\
\hline 342 & Printing \& Publishing \\
\hline 351 & Industrial Chemicals \\
\hline 352 & Other Chemicals \\
\hline 353 & Petroleum Refineries \\
\hline 354 & Misc. Petroleum \& Coal Products \\
\hline 355 & Rubber Products \\
\hline 356 & Plastic Products \\
\hline 361 & Pottery, China, Earthenware \\
\hline 362 & Glass \& Products \\
\hline 369 & Other Non-Metallic Mineral Products \\
\hline 371 & Iron \& Steel \\
\hline 372 & Non-Ferrous Metals \\
\hline 381 & Fabricated Metal Products \\
\hline 382 & Machinery, exc. Electrical \\
\hline 383 & Machinery, Electric \\
\hline 384 & Transportation Equipment \\
\hline 385 & Professional and Scientific Equipment \\
\hline 390 & Other Manufactured Products \\
\hline
\end{tabular}


C. Sample of Countries for each Regression

\begin{tabular}{|c|c|c|c|c|c|c|c|}
\hline country & $\# 1$ & $\# 2,3,4$ & $\# 5$ & \#6 & $\# 7$ & $\# 8$ & $\# 9$ \\
\hline Algeria & $\mathrm{x}$ & $\mathrm{x}$ & $\mathrm{x}$ & $\mathrm{x}$ & $\mathrm{x}$ & $x$ & $\mathrm{x}$ \\
\hline Argentina & $x$ & $\mathrm{x}$ & $\mathbf{x}$ & $\mathbf{x}$ & $\mathrm{x}$ & $x$ & $x$ \\
\hline Austria & $\mathrm{x}$ & $\mathrm{x}$ & $x$ & $\mathrm{x}$ & $\mathrm{x}$ & $\mathbf{x}$ & $\mathbf{x}$ \\
\hline Bangledesh & $\mathrm{x}$ & & & & & & \\
\hline Bolivia & $x$ & $\mathrm{x}$ & $\mathbf{x}$ & $x$ & $\mathrm{x}$ & $\mathbf{x}$ & $\mathrm{x}$ \\
\hline Brazil & $\mathrm{x}$ & $\mathrm{x}$ & $\mathrm{x}$ & $\mathrm{x}$ & $\mathrm{x}$ & $\mathrm{x}$ & $\mathbf{x}$ \\
\hline Cameroon & $\mathrm{x}$ & $\mathrm{x}$ & $\mathrm{x}$ & $\mathrm{x}$ & $\mathrm{x}$ & $\mathrm{x}$ & $\mathrm{x}$ \\
\hline Canada & $\mathrm{x}$ & $\mathrm{x}$ & $\mathrm{x}$ & $\mathrm{x}$ & $\mathrm{x}$ & $x$ & $\mathrm{x}$ \\
\hline Chile & $\mathrm{x}$ & $\mathrm{x}$ & $\mathrm{x}$ & $\mathbf{x}$ & $\mathbf{x}$ & $\mathrm{x}$ & $\mathrm{x}$ \\
\hline China & $x$ & $\mathrm{x}$ & $\mathrm{x}$ & & & & \\
\hline Colombia & $\mathrm{x}$ & $\mathrm{x}$ & $\mathrm{x}$ & $\mathrm{x}$ & $\mathrm{x}$ & $\mathbf{x}$ & $\mathrm{x}$ \\
\hline Cote D'Ivoire & $x$ & $\mathrm{x}$ & $\mathrm{x}$ & $\mathrm{x}$ & $\mathbf{x}$ & $\mathrm{x}$ & $\mathrm{x}$ \\
\hline Ecuador & $\mathrm{x}$ & $\mathbf{x}$ & $\mathrm{x}$ & $\mathrm{x}$ & $\mathbf{x}$ & $\mathrm{x}$ & $\mathrm{x}$ \\
\hline Egypt & & & $\mathrm{x}$ & & & $\mathrm{x}$ & \\
\hline El Salvador & $\mathrm{x}$ & $\mathrm{x}$ & $\mathrm{x}$ & & $\mathrm{x}$ & $\mathrm{x}$ & \\
\hline Ethiopia & $x$ & $\mathrm{x}$ & $\mathrm{x}$ & $\mathrm{x}$ & $\mathbf{x}$ & $\mathrm{x}$ & $\mathrm{x}$ \\
\hline France & $\mathrm{x}$ & $\mathbf{x}$ & $\mathrm{x}$ & $x$ & $\mathbf{x}$ & $\mathrm{x}$ & $\mathrm{x}$ \\
\hline Germany & $x$ & $\mathrm{x}$ & $\mathrm{x}$ & $\mathrm{x}$ & $x$ & $\mathrm{x}$ & $\mathrm{x}$ \\
\hline Indonesia & $\mathrm{x}$ & $\mathrm{x}$ & $\mathrm{x}$ & $x$ & $\mathrm{x}$ & $\mathrm{x}$ & $\mathrm{x}$ \\
\hline Italy & $\mathrm{x}$ & $\mathrm{x}$ & $\mathbf{x}$ & $x$ & $\mathrm{x}$ & $\mathrm{x}$ & $\mathrm{x}$ \\
\hline Japan & $\mathrm{x}$ & $\mathrm{x}$ & $\mathrm{x}$ & $\mathrm{x}$ & $\mathrm{x}$ & $\mathrm{x}$ & $\mathrm{x}$ \\
\hline Korea & $\mathrm{x}$ & $\mathrm{x}$ & $\mathbf{x}$ & $x$ & $\mathrm{x}$ & $\mathbf{x}$ & $\mathrm{x}$ \\
\hline Libya & $\mathrm{x}$ & & & & & & \\
\hline Mexico & $\mathrm{x}$ & $\mathrm{x}$ & $\mathrm{x}$ & $\mathbf{x}$ & $\mathrm{x}$ & $x$ & $\mathrm{x}$ \\
\hline Nicaragua & $\mathrm{x}$ & & & & & & \\
\hline Norway & $\mathrm{x}$ & $\mathrm{x}$ & $\mathrm{x}$ & $\mathrm{x}$ & 'x & $x$ & $\mathrm{x}$ \\
\hline Pakistan & $\mathrm{x}$ & $\mathrm{x}$ & $\mathrm{x}$ & $\mathrm{x}$ & $\mathrm{x}$ & $\mathrm{x}$ & $\mathrm{x}$ \\
\hline Peru & $\mathrm{x}$ & $x$ & $\mathrm{x}$ & $\mathrm{x}$ & $x$ & $\mathrm{x}$ & $\mathrm{x}$ \\
\hline Phillippines & $\mathrm{x}$ & $\mathrm{x}$ & $\mathrm{x}$ & $\mathrm{x}$ & $\mathrm{x}$ & $\mathrm{x}$ & $\mathrm{x}$ \\
\hline Portugal & $\mathrm{x}$ & $\mathrm{x}$ & $\mathrm{x}$ & $\mathrm{x}$ & $\mathrm{x}$ & $\mathrm{x}$ & $\mathbf{x}$ \\
\hline Senegal & $\mathrm{x}$ & $\mathrm{x}$ & $\mathrm{x}$ & & $\mathrm{x}$ & $\mathrm{x}$ & \\
\hline Somalia & $\mathrm{x}$ & $\mathrm{x}$ & $\mathrm{x}$ & $\mathbf{x}$ & $\mathbf{x}$ & $\mathrm{x}$ & $x$ \\
\hline South Africa & $\mathrm{x}$ & $\mathrm{x}$ & & & & & \\
\hline Thailand & $\mathrm{x}$ & $\mathrm{x}$ & $\mathrm{x}$ & $\mathrm{x}$ & $\mathrm{x}$ & $\mathrm{x}$ & $\mathrm{x}$ \\
\hline Tunisia & $\mathrm{x}$ & $\mathrm{x}$ & $\mathrm{x}$ & $\mathrm{x}$ & $\mathbf{x}$ & $x$ & $\mathrm{x}$ \\
\hline Turkey & $\mathrm{x}$ & $\mathrm{x}$ & $\mathrm{x}$ & $\mathrm{x}$ & $\mathrm{x}$ & $\mathrm{x}$ & $\mathrm{x}$ \\
\hline Uruguay & $\mathrm{x}$ & $\mathrm{x}$ & $\mathrm{x}$ & $\mathrm{x}$ & $\mathrm{x}$ & $\mathrm{x}$ & $\mathrm{x}$ \\
\hline Venezuela & $\mathrm{x}$ & $x$ & $\mathrm{x}$ & $\mathrm{x}$ & $x$ & $\mathrm{x}$ & $\mathrm{x}$ \\
\hline Zambia & $\mathrm{x}$ & $\mathbf{x}$ & $\mathrm{x}$ & $\mathrm{x}$ & $\mathbf{x}$ & $\mathrm{x}$ & $\mathrm{x}$ \\
\hline
\end{tabular}


D. List of Basic Variable Names, Sources and Definitions

\begin{tabular}{|lll|}
\hline Variable Name & Source* & Brief Definition \\
\hline GPROD & WT & Growth of gross-output in manufacturing per employee \\
GVAPROD & UNIDO & Growth of value-added in manufacturing per employee \\
PRE1973 & & Pre-1973 dummy variable \\
Ldc & & Less developed country dummy variable \\
Dev & & Industrialized country dummy variable \\
GOHERF & UNIDO & Herfindahl index defined over gross-output \\
VAHERF & UNIDO & Herfindahl index defined over value-added \\
WTHERF & UNIDO & Herfindahl index weighted by value-added per employee \\
$G F I V N I V$ & WT & (Instrumented) growth of fixed investment \\
TVAL & SH & Share of exports+imports in GDP \\
$G O V S H A R E$ & SH & Share of goverment spending in GDP \\
$I N F$ & WT & Inflation rate \\
$D$ & & Prefix for first-differenced variables \\
$i$ & & Suffix indicating the $i^{\text {th }}$ lag of the variable \\
\hline
\end{tabular}

* WT $=$ World Tables; $\mathrm{SH}=$ Summers and Heston; UNIDO=World Bank 


\section{References}

[1] T.W. Anderson and Cheng Hsiao. Formulation and estimation of dynamic models using panel data. Journal of Econometrics, 18, 1982.

[2] David K. Backus, Patrick J. Kehoe, and Timothy J. Kehoe. In search of scale effects in trade and growth. Journal of Economic Theory, 58, December 1992.

[3] Hollis B. Chenery and Alan M. Strout. Foreign assistance and economic development. American Economic Review, 56(4), September 1966.

[4] Sebastian Edwards. Trade orientation, distortions and growth in developing countries. Journal of Development Economics, 39(1), 1992.

[5] Sebastian Edwards. Openness, trade liberalization, and growth in developing countries. Journal of Economic Literature, XXXI(3), September 1993.

[6] Gene M. Grossman and Elhanan Helpman. Growth and welfare in a small open economy. Working Paper 2809, NBER, 1989.

[7] Gene M. Grossman and Elhanan Helpman. Innovation and Growth in the Global Economy. MIT Press, 1992.

[8] Ann Harrison. Openness and growth: a time-series, cross-country analysis for developing countries. Journal of Development Economics, 48(2), 1996.

[9] D. Holtz-Eakin, W. Newey, and H. Rosen. Estimating vector autoregressions with panel data. Econometrica, 56(6), November 1988.

[10] Anne O. Krueger. The political economy of the rent seeking society. American Economic Review, 64, 1974.

[11] Anne O. Krueger. The effects of trade strategies on growth. Finance $\mathcal{E}$ Development, June 1983.

[12] Edward E. Leamer. Measures of openness. In Trade Policy Issues and Empirical Analysis. The University of Chicago Press Ltd., 1988.

[13] Andrew Levin and Chien-Fu Lin. Unit root tests in panel data: Asymptotic and finitesample properties. Discussion Paper 92-23, University of California, San Diego, 1992.

[14] Robert E. Lucas. On the mechanics of economic development. Journal of Monetary Economics, 22(3):3-42, June 1988. 
[15] Gerald M. Meier. Leading Issues in Economic Development. Oxford University Press, New York, NY, 1989.

[16] Stephen Nickell. Biases in dynamic models with fixed effects. Econometrica, 49(6), November 1981 .

[17] Danny Quah. Empirics for economic growth and convergence. European Economic Review, 40(6), 1996.

[18] Danny Quah and James E. Rauch. Openness and the rate of economic growth. Preliminary Draft, UCSD, 1990.

[19] Luis A. Rivera-Batiz and Paul M. Romer. Economic integration and endogenous growth. Quarterly Journal of Economics, 106(2), May 1991.

[20] Nouriel Roubini and Xaxier Sala i Martin. Financial development, the trade regime, and economic growth. Working Paper 3876, NBER, 1991.

[21] Diana Weinhold. Investment, growth and causality testing in panel data. University of California, San Diego, 1993. 